\title{
ANALISIS FAKTOR-FAKTOR YANG MEMPENGARUHI MINAT BERWIRAUSAHA PADA MAHASISWA PROGRAM STUDI MANAJEMEN FAKULTAS EKONOMI UNIVERSITAS KADIRI
}

\author{
Afif Nur Rahmadi \\ Fakultas Ekonomi, Universitas Kadiri \\ afifnur@unik-kediri.ac.id \\ Budi Heryanto \\ Fakultas Ekonomi, Universitas Kadiri \\ budiheryanto@unik-kediri.ac.id
}

\begin{abstract}
Abstrak
Penelitian ini bertujuan untuk mengetahui minat berwirausaha dan faktor-faktor yang mempengaruhi minat berwirausaha pada mahasiswa Prodi Manajemen Fakultas Ekonomi Universitas Kadiri. Penelitian ini menggunakan metode deskriptif kuantitatif. Populasi penelitian ini diambil dari mahasiswa Prodi Manajemen dengan sampel penelitian sebanyak 74 mahasiswa. Teknik penentuan sampel yang digunakan adalah Purposive Sampling. Teknik analisis data yang digunakan menggunakan SEM (Structural Equation Model) dimana alat yang dgunakan untuk mengembangkan model memakai SmartPLS3. Sedangkan untuk mencari faktor yang memengaruhi minat berwirausaha menggunakan analisis faktor yang disebut Exploratory Factor Analysis. Berdasarkan hasil analisis data dan pembahasan dapat ditarik kesimpulan bahwa minat berwirausaha mahasiswa prodi Manajemen Fakultas Ekoonomi Universitas Kadiri sangat tinggi dan dari hasil uji statistik dari beberapa faktor yang mempengaruhi minat berwirausaha mahasiswa pada mahasiswa adalah faktor inovasi dan kreatifitas serta lingkungan teknologi. Sedangkan faktor-faktor yang lain seperti lingkungan sosial dan keluarga serta memiliki modal tidak signifikan, karena nilai t-statistiknya dibawah dari nilai kritis $\pm 1,96$.
\end{abstract}

Kata kunci : Minat berwirausaha, faktor-faktor yang mempengaruhi minat berwirausaha

\section{PENDAHULUAN}

\section{Latar Belakang}

Indonesia memiliki potensi ekonomi yang besar, dengan kekayaan alam melimpah, penduduk dengan jumlah besar dan tenaga kerja muda yang juga dengan jumlah besar. Ini bisa dilihat populasi penduduk Indonesia yang sekarang sudah 250 juta. Disinilah sebenarnya muncul suatu kesempatan bagi wirausaha baru untuk mengambil peluang ini agar bisa mencapai suatu tujuan wirausaha tersebut. Selain itu, lapangan pekerjaan dari perusahaanperusahaan besar sekarang mulai berkurang, serta banyaknya perusahaan besar yang menerima tenaga kerja dengan sistem kontrak. Oleh sebab itu dengan mempunyai minat untuk berwirausaha maka mendorong terciptanya lapangan pekerjaan baru yang akhirnya menciptakan suatu kemakmuran. 


\section{Rumusan Masalah}

Berdasarkan latar belakang di atas, maka peneliti merumuskan permasalahan faktorfaktor apa saja yang mempengaruhi mahasiswa dalam minat berwirausaha.

\section{Tujuan Peelitian}

Berdasarkan rumusan masalah, maka tujuan dalam penelitian ini adalah menganalisis faktor-faktor yang mempengaruhi mahasiswa dalam minat berwirausaha.

\section{TINJAUAN PUSTAKA}

\section{Penelitian Terdahulu}

Penelitian dari Hanum Risfi Mahanani (2014) dengan judul Analisis Pengaruh Faktor Internal dan Faktor Eksternal Terhadap Minat Berwirausaha (Studi pada siswa SMAN 1 Semarang) yang menunjukkan bahwa variabel lingkungan sosial dan keluarga serta variabel lingkungan teknologi masing-masing berpengaruh positif dan signifikan terhadap minat berwirausaha. Sedangkan untuk variabel baik itu percaya diri, berorientasi pada tugas dan hasil, keberanian mengambil risiko, kepemimpinan, berorientasi pada masa depan, inovasi dan kreatifitas, serta lingkungan sekolah tidak ada pengaruh signifikan terhadap minat berwirausaha.

Penelitian dari Aflit Nuryulia Praswati (2014) dengan judul Analisis Faktor-Faktor yang Mempengaruhi Minat Wirausaha di Kalangan Mahasiswa Studi kasus: fakultas Ekonomi dan Bisnis Universitas Muhammmadiyah Surakarta, yang menyimpulkan bahwa Hasil dari penelitian ini telah menjawab masalah yang telah diajukan yaitu faktor-faktor apa saja yang berpengaruh terhadap minat wirausaha. Faktor-faktor yang mempunyai pengaruh positif dan signifikan terhadap minat wirausaha adalah variabel keinginan menjadi bos, kepemimpinan, keuangan dan lingkungan. Variabel harga diri mempunyai pengaruh negatif dan signifikan terhadap minat wirausaha. Dan variabel tantangan pribadi dan fleksibilitas mempunyai pengaruh negatif dan tidak signifikan terhadap minat wirausaha. Dari 125 responden, terdapat 73 mahasiswa yang menyatakan keinginannya menjadi wirausaha. Hal ini menandakan bahwa minat wirausaha mahasiswa fakultas ekonomi dan bisnis di Universitas muhammadiyah Surakarta termasuk tinggi.

Penelitian Komsi Koranti (2013) dengan judul Analisis Pengaruh Faktor Eksternal dan Internal Terhadap Minat Berwirausaha dengan menyimpulkan bahwa variabel yang paling berpengaruh terhadap minat berwirausaha mahasiswa Universitas Gunadarma adalah motivasi berwirausaha. Pengaruh variabel berikutnya secara berurutan adalah kepribadian, lingkungan keluarga dan lingkungan sekitar. Hasil penelitian juga menunjukkan bahwa semua variabel lingkungan eksternal maupun internal mempunyai pengaruh positif dan signifikan terhadap minat berwirausaha mahasiswa Universitas Gunadarma, baik secara parsial maupun simultan.

\section{Pengertian Kewirausahaan}

Wirausaha adalah terjemahan dari kata entrepreneur. Wirausaha adalah orang yang mampu menciptakan bisnis baru dan orang yang biasanya langsung berhadapan dengan 
risiko mampu mengidentifikasikan dalam mencapai keberhasilan. Wirausaha mampu mengidentifikasikan berbagai kesepakatan dan mencurahkan seluruh sumber daya yang ia miliki untuk mengubah kesempatan itu suatu yang menguntungkan (nurain, 2011). Wirausahawan adalah orang yang bertanggung jawab dalam menyusun, mengelola dan mengukur risiko suatu usaha (Machfoedz, 2004).

Menurut Meredith (Yuyus Suryana dan kartib bayu, 2011), “wirausaha adalah orangorang yang mempunyai kemampuan melihat dan menilai kesempatan usaha mengumpulkan serta sumber daya yang dibutuhkan guna mengambil keuntungan daripadanya dan mengambil tindakan yang tepat guna memastikan kesuksesan".

MC Clellan dalam Alma (2007), mengemukakan bahwa kewirausahaan (entrepreneurship) ditentukan oleh motif berprestasi (achievement), optimisme (optimism), sikap-sikap nilai (value attitudes) dan status kewirausahaan (enterpreneural status) atau keberhasilan.

\section{Pengertian Minat Berwirausaha}

Minat (interest) adalah rasa lebih suka dan rasa keterkaitan pada suatu hal atau aktivitas, tanpa ada yang menyuruh. Pada dasarnya minat merupakan penerimaan akan suatu hubuga antara diri sendiri dengan sesuatu di luar dirinya. Semakin kuat atau dekat hubungan tersebut, maka semakin besar minatnya (Djaali, 2008). Apabila seseorang telah melaksanakan kesungguhannya kepada suatu objek maka minat ini akan menuntun seseorang untuk memperhatikan lebih rinci dan mempunyai keinginan untuk ikut atau memiliki objek tersebut.

Selain itu minat merupakan salah satu aspek psikis manusia yang mendorongnya untuk memperoleh sesuatu atau untuk mencapai suatu tujuan, sehingga minat mengandung unsur keinginan untuk mengetahui dan mempelajari dari sesuatu yang diinginkannya itu sebagai kebutuhannya. Minat merupakan suatu keinginan yang cenderung menetap pada diri seseorang untuk mengarahkan pada suatu pilihan tertentu sebagai kebutuhannya, kemudian dilanjutkan untuk diwujudkan dalam tindakan nyata dengan adanya perhatian pada objek yang diinginkannya itu untuk mencari informasi sebagai wawasan bagi dirinya (Febri, 2012).

Sedangakan minat berwirausaha menurut Fuadi (2009) adalah keinginan, ketertarikan, serta kesediaan untuk bekerja keras atau berkemauan keras untuk berusaha secara maksimal untuk memenuhi kebutuhan hidupnya tanpa merasa takut dengan resiko yang akan terjadi, serta berkemauan keras untuk belajar dari kegagalan.

Dalam penelitian Mahesa (2012) tentang minat dan wirausaha di atas, minat berwirausaha adalah kecenderungan hati dalam diri subyek untuk tertarik menciptakan suatu usaha yang kemudian mengorganisir, mengatur, menanggung risiko dan mengembangkan usaha yang diciptakannya tersebut.

Menurut Fatrika, et. al. (2009) minat berwirausaha tidak dibawa sejak lahir namun berkembang sesuai dengan faktor-faktor yang mempengaruhinya. Faktor-faktor yang mempengaruhi minat berwirausaha meliputi karakteristik (jenis kelamin dan usia), lingkungan

(lingkungan keluarga, lingkungan pendidikan, lingkungan masyarakat), kepribadian (ektraversi, kesepahaman / Agreebleeness, berani mengambil resiko, kebutuhan berprestasi dan independen, evaluasi diri serta overcon_dence / kepercayaan diri yang lebih) dan motif 
berwirausaha (bekerja dan penyaluran ide kreatif).

Subandono (2007), mengemukakan bahwa minat wirausaha adalah kecenderungan hati dalam diri subjek untuk tertarik menciptakan suatu usaha yang kemudian memgorganisir, mengatur, menanggung risiko dan mengembangkan usaha yang diciptakannya tersebut.

Menurut (Suryana, 2006), seseorang yang memiliki bakat kewirausahaan dapat mengembangkan bakatnya melalui pendidikan. Mereka yang menjadi wirausaha adalah orang-orang yang mengenal potensi dan belajar mengembangkannya untuk menangkap peluang serta mengorganisasi usaha dalam mewujudkan cita-citanya.

Dari penjelasan diatas maka mahasiswa akan mempunyai suatu dorongan yang kuat untuk berwirasusaha apabila seseorang atau mahasiswa mempunyai minat berwirausaha yang lebih besar. Dengan adanya minat tersebut, maka akan mendorong mahasiswa untuk melakukan suatu hal terntu yang didalamnya terkandung suatu motivasi yang menyebabkan melakukan suatu hal atau aktivitas sesuai dengan tujuan. Dengan demikian, dengan adanya dorongan yang kuat maka sesuatu cita-cita atau keinginan untuk berwirausaha akan bisa terwujud sehingga apabila keinginan tersebut sudah terpenuhi maka akan timbul suatu kepuasan, yang dimana kepuasan itu sendiri sifatnya menyenangkan.

\section{Lingkungan Sosial dan Keluarga}

Menurut Wibowo (2011) lingkungan sosial merupakan lingkungan masyarakat dimana terjadi interaksi antara individu satu dengan yang lain, individu dengan kelompok, atau kelompok.

Berkaitan dengan lingkungan keluarga, maka peran keluarga sangat penting dalam menumbuhkan minat anak. Orang tua merupakan pendidik pertama dan sebagai tumpuan dalam bimbingan kasih sayang yang utama. Maka orang tualah yang banyak memberikan pengaruh dan warna kepribadian terhadap seorang anak. Dengan demikian mengingat pentingnya pendidikan di lingkungan keluarga, maka pengaruh di lingkungan keluarga terhadap anak dapat mempengaruhi apa yang diminati oleh anak (Wibowo, 2011).

\section{Inovasi \& Kreatifitas}

Kreatifitas adalah kemampuan mengembangkan ide dan cara-cara baru dalam memecahkan masalah dan menemukan peluang. Sedangkan inovasi adalah kemampuan menerapkan kreativitas dalam rangka memecahan masalah dan menemukan peluang (Suryana, 2006).

Menurut Suryana (2006), inovasi adalah kreatifitas yang diterjemahkan menjadi sesuatu yang dapat diimplementasikan dan memberikan nilai tambah atas sumber daya yang kita miliki. Sifat inovatif dapat ditumbuhkembangkan dengan memahami bahwa inovasi adalah suatu kerja keras, terobosan, dan kaizen (perbaikan yang terus-menerus).

Inovasi merupaka fungsi utama dalam kewirausahaan. Inovasi adalah suatu proses untuk mengubah kesempatan menjadi ide yang dapat dipasarkan. Inovasi lebih dari sekedar ide yang baik (Machfoedz, 2004).

Dari pengertian diatas memiliki inisiatif, selalu mengutamakan imajinasi, memanfaatkan perbedaan, sikap tidak pernah puas, orisinil berani tampil beda bisa menjadikan 
indakator pertanyaan didalam suatu penelitian.

\section{Lingkungan Teknologi}

Semakin canggihnya dunia teknologi, semakin canggih pula cara orang menyampaikan informasi. Dengan adanya informasi yang semakin mudah didapatkan. Kemajuan teknologi saat ini tidak bisa dipisahkan dari kehidupan masyarakat. Berbagai informasi yang terjadi di berbagai belahan dunia kini telah dapat langsung diketahui berkat kemajuan teknologi (globalisasi). Kemajuan teknologi ini menyebabkan perubahan yang begitu besar pada kehidupan umat manusia dengan segala peradaban dan kebudayaannya. Perubahan ini juga memberikan dampak yang begitu besar terhadap transformasi nilai-nilai yang ada di masyarakat. Kemajuan teknologi seperti televisi, telepon dan telepon genggam (HP), bahkan internet. Saat ini dapat kita lihat betapa kemajuan teknologi telah mempengaruhi gaya hidup dan pola pikir masyarakat, terutama di kalangan remaja (Ibnu, 2013).

\section{Memiliki Modal}

Alma (2010) mengungkapkan bahwa tersedianya modal akan memicu minat seseorang dalam berwirausaha, misalnya memiliki bangunan yang lokasinya strategis akan memicu minat seseorang untuk membuka usaha di lokasi tersebut.

Dari pendapat diatas keuangan modal yang cukup dan tempat strategis dapat memicu minat seseorang untuk membuka suatau wirausaha.

\section{Kerangka Berpikir}

\section{Gambar 2.1 Kerangka Berpikir}

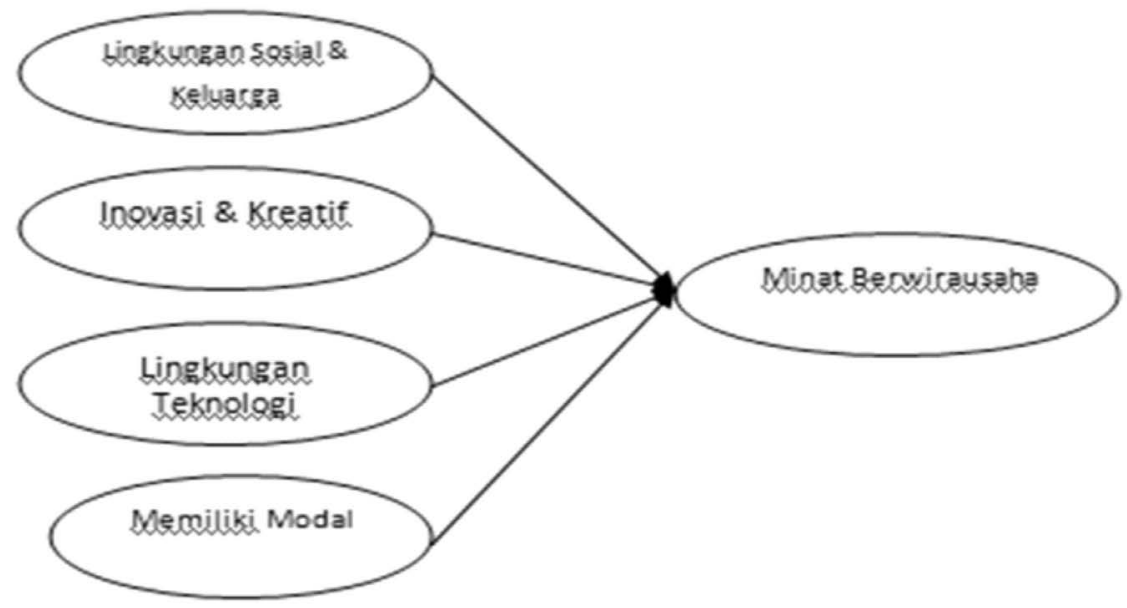

\section{Hipotesis}

Hipotesis dari penelitian ini adalah

H1 : Variabel lingkungan social dan keluarga berpengaruh secara positif terhadap minat mahasiswa Program Studi Manajemen Fakultas Ekonomi Universitas Kadiri 
H2 : Variabel inovasi dan kreatifitas berpengaruh secara positif terhadap minat mahasiswa Program Studi Manajemen Fakultas Ekonomi Universitas Kadiri

H3 : Variabel lingkungan Teknologi berpengaruh secara positif terhadap minat mahasiswa Program Studi Manajemen Fakultas Ekonomi Universitas Kadiri

H4 : Variabel memiliki modal berpengaruh secara positif terhadap minat mahasiswa Program Studi Manajemen Fakultas Ekonomi Universitas Kadiri

\section{METODE PENELITIAN}

\section{Populasi dan Sampel Penelitian}

Populasi adalah gabungan dari seluruh elemen yang berbentuk peristiwa, hal atau orang yang memiliki karakteristik yang serupa yang menjadi pusat perhatian seorang peneliti karena itu dipandang sebagai sebuah semesta penelitian (Ferdinand, 2006). Populasi dalam penelitian ini adalah mahasiswa Fakultas Ekonomi Program Studi Manajemen Universitas Kadiri dengan criteria yang telah mengikuti mata kuliah kewirausahaan dan mahasiswa semester 6 (enam) tahun angkatan 2013 sejumlah 372 mahasiswa.

Sampel penelitian diambil dari populasi menggunakan teori menentukan ukuran sampel menurut Gay dan Diehl (1996) yaitu : Penelitian deskriptif, minimal diambil sampel $10 \%$ dari populasinya. Jika populasinya besar, maka minimal $20 \%$ dari populasi.

\section{Metode Pengambilan Sampel}

Menurut Sugiyono (2011), sampel adalah bagian dari jumlah dan karakteristik yang dimiliki oleh populasi. Sample merupakan bagian yang berguna bagi tujuan penelitian populasi dan aspek-aspeknya. Teknik penarikan sampel dalam penelitian ini menggunakan non probability sampling, yaitu teknik yang tidak memberikan peluang atau kesempatan sama bagi setiap unsur atau anggota populasi untuk dipilih menjadi sampel. Jenis sampel ini tidak dipilih secara acak.

Teknik penentuan sampel yang digunakan adalah Purposive Sampling dimana penelitian ini tidak dilakukan pada seluruh populasi, tapi terfokus pada target. Purposive Sampling artinya bahwa pengambilan sampel terbatas pada jenis orang tertentu yang dapat memberikan informasi yang diinginkan (Sekaran, 2006). Kriteria-kriteria tertentu yang telah dibuat terhadap obyek yang sesuai dengan tujuan penelitian dalam hal ini penelitian dilakukan pada mahasiswa Prodi Manajemen Fakultas Ekonomi Universitas Kadiri yang mahasiswanya yang telah mengikuti mata kuliah kewirausahaan sejumlah 74 mahasiswa.

\section{Metode Pengumpulan Data}

Studi pustaka merupakan pengumpulan data yang dilakukan dengan membaca bukubuku literatur, jurnal-jurnal, internet, majalah, dan penelitian terdahulu yang berkaitan dengan penelitian yang sedang dilakukan (Baskoro, 2011).

Studi Lapangan yang terdiri dari kuesioner dan wawancara. Dimana kuesioner Dalam suatu penelitian ilmiah, metode pengumpulan data dimaksudkan untuk memperoleh bahan-bahan yang relevan, akurat, dan terpercaya (Indrianto dan Supomo, 2003). Dalam 
penelitian ini pengumpulan data menggunakan kuesioner atau dikenal juga dengan sebutan angket. Kuesioner merupakan teknik pengumpulan data yang dilakukan dengan cara memberi seperangkat pertanyaan tertulis kepada responden untuk diisi. Dalam kuesioner ini sendiri terbagi dalam beberapa halaman yang mewakili variabel yang ada. Pertanyaan yang terlampir dalam kuesioner ini akan mewakili tiap-tiap indikator variabel yang telah ditentukan. Pengukuran variabel sendiri akan dilakukan dengan skala Likert yang menggunakan metode scoring sebagai berikut:

$\begin{array}{ll}\text { Sangat Setuju (SS) } & =\text { Diberi bobot/Skor } 5 \\ \text { Setuju (S) } & =\text { Diberi bobot/skor } 4 \\ \text { Netral (N) } & =\text { Diberi bobot/skor } 3 \\ \text { Tidak Setuju } & =\text { Diberi bobot/skor } 2 \\ \text { Sangat Tidak Setuju } & =\text { Diberi bobot/skor } 1\end{array}$

Angka 1 menunjukkan bahwa responden tidak mendukung terhadap pertanyaan yang diberikan. Sedangakan angka 5 menunjukkan bahwa responden mendukung terhadap pertanyaan yang diberikan.

Sedangkan dalam wawancara metode ini dilakukan untuk mengetahi data-data sekunder biodata mahasiswa. Selain dengan melakukan penyebaran kuesioner, data-data yang terkumpul juga berasal dari riset lapangan, dimana data dapat diperoleh dengan melakukan penelitian langsung untuk mendapatkan data.

\section{HASIL DAN PEMBAHASAN Deskriptif Data Penelitian}

Data penelitian dikumpulkan dengan cara membagikan kuesioner secara langsung kepada responden yang berhasil ditemui. Kuesioner diperoleh dengan cara peneliti menemui langsung responden dan memberikan kuesioner untuk diisi oleh para responden yaitu mahasiswa Prodi Manajemen Fakultas Ekonomi Universitas Kadiri.

Pengumpulan data secara langsung dengan menemui responden, hal ini bertujuan agar lebih efektif untuk meningkatkan respon rate responden dalam penelitian ini. Survey dengan kuesioner dilakukan pada bulan Juli-Agustus 2016 dengan mengambil 74 responden.

\section{Deskripsi Karakteristik Responden Jenis Kelamin}

Responden dari peneleitian ini sebanyak 74 responden yang terdiri dari para mahasiswa semester 6 yang sudah mengikuti mata kuliah kewirausahaan. Adapun frekuensi dari jenis kelamin responden adalah sebagai berikut :

Tabel 4.1 Frekuensi responden dari umum

\begin{tabular}{|c|c|c|}
\hline Jenis Kelamin & Jumlah & Persentate \\
\hline Laki-Laki & 27 & 36.49 \\
\hline Perempuan & 47 & 63.51 \\
\hline & 74 & 100 \\
\hline
\end{tabular}

Sumber : Data Primer dioalah, 2016. 
Berdasarkan dari tabel 4.1 dapat diketahui tentang jenis kelamin responden yang didapat paling banyak dari perempuan dengan jumlah 47 responden atau sekitar $63,51 \%$ dari jumlah responden dan sedangkan untuk laki-laki sekitar 27 responden atau sekitar 36, 49\% dari jumlah total responden.

\section{Umur Responden}

Data mengenai umur responden disini, dibagi tiga kelompok, yaitu kelompok pertama umur dibawah atau sama dengan umur 22 tahun, kelompok kedua umur 23 tahun sampai dengan 27 tahun dan kelompok ketiga umur lebih atau sampai dengan 28 tahun. Adapun data umur responden adalah sebagai berikut :

Tabel 4.2 Umur Responden

\begin{tabular}{|c|c|c|}
\hline Umur & Jumlah & Persentaste \\
\hline$\geq 22$ & 45 & 60.81 \\
\hline 23 s.d 27 & 24 & 32.43 \\
\hline $28 \leq$ & 5 & 6.76 \\
\hline & 74 & 100 \\
\hline
\end{tabular}

Berdasarkan data pada table 4.2 diatas maka dapat diketahui tentang usia responden. Umur responden yang menjadi sampel diatas yaitu sebanyak 45 responden atau sekitar $60,81 \%$ dari responden yang berumur dibawah atau sama dengan 22 tahun pada saat diwawancarai dan diberi kuisioner. Sedangkan umur 23 sampai dengan 27 tahun sebanyak 24 responden atau sebesar 32, 43\% dari jumlah responden dan sisanya berumur 28 tahun keatas atau sama sebanyak 5 orang atau sebesar $6,76 \%$.

\section{Jenis Pekerjaan Orang Tua Responden}

Pada data jenis ini, peneliti mengelompokan jenis pekerjaan orang tua responden sebanyak 6 kelompok diantaranya : PNS, TNI/POLRI, Guru /Dosen, Karyawan Swasta, Wirausaha, Petani/Peternak dan yang terakhir adalah dan lain-lain. Adapun data responden adalah sebagai berikut:

Tabel 4.3 Jenis Pekerjaan Orang Tua Responden

\begin{tabular}{|l|c|c|}
\hline Pekerjaan Orang Tua & Jumlah & Persentase \\
\hline PNS & 8 & 10.81 \\
TNI/POLRI & 0 & 0.00 \\
Guru/Dosen & 2 & 2.70 \\
Karyawan Swasta & 16 & 21.62 \\
Wirausaha & 15 & 20.27 \\
Petani/Peternak & 23 & 31.08 \\
Dll & 10 & 13.51 \\
\hline \multicolumn{2}{|l|}{} \\
Sumber: Data primer dioalah, 2016
\end{tabular}


Berdasarkan data dari table 4.3 dapat diketahui jenis pekerjaan orang tua responden yang sebagian besar pekerjaan orang tua menjadi karyawan swasta sebanyak 23 responden atau sebesar $31,08 \%$ dari jumlah responden, selanjutnya jenis pekerjaan orangtua sebagai karyawan swasta sebanyak 16 responden atau sebesar $21,62 \%$ dari jumlah responden dan untuk pekerjaan orang tua sebagai wirausaha sebanyak 15 responden atau sebesar $20,27 \%$ dari jumlah responden. Dan sisanya jenis pekerjaan orang tua responden sebanyak 20 orang bekerja sebagai PNS 8 responden, Guru/Dosen 2 responden dan lain-lain 10 responden.

\section{Pengujian Validitas dan Reliabilitas}

\section{Uji Validitas}

Uji validitas digunakan untuk mengukur sah/valid atau tidaknya suatu kuesioner. Kuesioner dikatakan valid jika pertanyaan pada kuesioner mampu untuk mengungkapkan sesuatu yang akan diukur oleh kuesioner tersebut. Validitas suatu instrumen akan menggambarkan tingkat kemampuan alat ukur yang digunakan untuk mengungkapkan sesuatu yang menjadi sasaran pokok pengukuran. Dengan demikian permasalahan validitas instrumen (angket) akan menunjukkan pada mampu tidaknya instrumen (angket) tersebut untuk mengukur objek yang diukur. Apabila instrumen tersebut mampu untuk mengukur apa yang diukur, maka disebut valid dan sebaliknya, apabila tidak mampu untuk mengukur apa yang diukur, maka dinyatakan tidak valid.

Penghitungan tersebut dilakukan untuk seluruh variabel yang instrumen pengukurannya menggunakan angket atau bahan tes. Kriteria yang digunakan atau batas minimum suatu instrumen/angket dinyatakan valid atau dianggap memenuhi syarat ada beberapa cara antara lain:

a. Harga koefisien korelasi yang diperoleh dari analisis dibandingkan dengan harga koefisien korelasi pada tabel dengan tingkat kepercayaan yang telah dipilih.

b. Dibuat suatu ukuran tertentu, misalnya batas minimum 0,3. Jadi apabila harga koefisien korelasi antara butir dengan skor total kurang dari 0,3 maka butir atau item pertanyaan dalam instrumen tersebut dinyatakan tidak valid. Dengan demikian suatu instrumen dinyatakan valid apabila harga koefisien $r$ hitung $\geq 0,3$.

Hasil uji validitas dapat dilihat pada table 4.4 yang menandakan bahwa semua pertanyaan valid

Tabel 4.4 Avarage Variance Extracted (AVE)

\begin{tabular}{|l|c|r|r|r|r|}
\hline & $\begin{array}{c}\text { Original } \\
\text { Sample } \\
(\mathbf{O})\end{array}$ & $\begin{array}{c}\text { Sample } \\
\text { Mean (M) }\end{array}$ & $\begin{array}{c}\text { Standard } \\
\text { Deviation } \\
\text { (STDEV) }\end{array}$ & $\begin{array}{c}\text { T Statistics } \\
\text { (|O/STDEV|) }\end{array}$ & $\begin{array}{c}\mathbf{P} \\
\text { Values }\end{array}$ \\
\hline INOV \& KREATIVITAS & 0.545 & 0.544 & 0.050 & 10.990 & 0.000 \\
LING SOS \& KEL & 0.362 & 0.369 & 0.043 & 8.328 & 0.000 \\
LING TEKNOLOGI & 0.908 & 0.904 & 0.032 & 28.302 & 0.000 \\
MEMILIKI MODAL & 0.809 & 0.747 & 0.161 & 5.038 & 0.000 \\
MINAT BERWIRAUSAHA & 0.720 & 0.723 & 0.045 & 16.129 & 0.000 \\
\hline
\end{tabular}

Sumber: Hasil pengolahan SmartPLS, 2016. 


\section{Uji Reliabilitas}

Reliabilitas adalah alat untuk mengukur suatu kuesioner yang merupakan indikator dari variabel atau konstruk. Butir pertanyaan dikatakan reliable atau andal apabila jawaban seseorang terhadap pertanyaan adalah konsisten. Reabilitas instrumen menggambarkan pada kemantapan dan keajegan alat ukur yang digunakan. Suatu alat ukur atau instrumen dikatakan memiliki reliabialitas yang baik apabila alat ukur atau instrumen tersebut selalu memberikan hasil yang sama meskipun digunakan berkali-kali. Instrumen yang reliabel akan menghasilkan data yang sesuai dengan kondisi sesungguhnya. Dalam penelitian ini uji reliabilitas menggunakan kaidah alpha cronbach, karena instrumen yang digunakan mempunyai rentang nilai, dengan rumus (Arikunto,2002:152):

Dari uji reliabilitas maka hasilnya dapat dilihat pada table 4.5 seperti berikut:

Tabel 4.5 Cronbach's Alpha

\begin{tabular}{|l|r|r|r|r|r|}
\hline & $\begin{array}{l}\text { Original } \\
\text { Sample } \\
\text { (O) }\end{array}$ & $\begin{array}{l}\text { Sample } \\
\text { Mean } \\
\text { (M) }\end{array}$ & $\begin{array}{l}\text { Standard } \\
\text { Deviation } \\
\text { (STDEV) }\end{array}$ & $\begin{array}{l}\text { T Statistics } \\
\text { (|O/STDEV|) }\end{array}$ & $\begin{array}{l}\text { P } \\
\text { Values }\end{array}$ \\
\hline INOV \& KREATIVITAS & 0.833 & 0.833 & 0.031 & 27.138 & 0.000 \\
\hline LING SOS \& KEL & 0.401 & 0.394 & 0.123 & 3.272 & 0.001 \\
\hline LING TEKNOLOGI & 0.899 & 0.893 & 0.039 & 23.105 & 0.000 \\
\hline MEMILIKI MODAL & 0.816 & 0.810 & 0.071 & 11.490 & 0.000 \\
\hline MINAT BERWIRAUSAHA & 0.804 & 0.807 & 0.041 & 19.462 & 0.000 \\
\hline
\end{tabular}

Sumber: Hasil pengolahan SmartPLS, 2016

Uji reliabilitas dengan melihat Alpha Cronbach, dimana suatu variabel laten dikatakan reliable jika nilai Alpha Cronbach $>0,6$. Diperoleh informasi dari tabel diatas bahwa hanya 3 variabel yang memiliki nilai Alpha Cronbach $>0,6$ yang berarti reliabel, akan tetatapi ada 1 (satu) variabel yang Alpha Cronbach < 0,6 yang berarti tidak reliabel yaitu variabel lingkungan sosial dan keluarga.

\section{ANALISIS MODEL PENELITIAN}

\section{Model Struktural}

\section{Pengembangan model berbasis teori}

Langkah pengembangan model teoritis dilakukan serangkaian eksplorasi ilmiah melalui telah pustaka guna mendapatkan justifikasi atas model teorities yang akan dikembangkan. SEM digunakan untuk mengkonfirmasi model teorities yang akan dikembangkan. SEM digunakan untuk mengkonfirmasi model teorities tersebut melalui data empiric. SEM merupakan sebuah confirmatory technique. Teknik ini merupakan teknik menguji teori baru atau teori yang sudah dikembangkan dan yang akan diuji lagi secara empiris.

\section{Pengembangan Diagram alur (path diagram)}

Model teoritis yang telah dibangun pada tahap pertama akan digambarkan dalam sebuah diagram alur, agar mempermudah untuk melihat hubungan kausalitas yang ingin diuji. Dalam diagram alur, hubungan antar konstruk akan dinyatakan melalui anak panah. Anak 
panah yang lurus menunjukkan sebuah hubungan kausal yang langsung antara satu konstruksi dengan konstruksi lainnya. Berdasarkan landasan teori maka dibuat diagram jalur SEM sebagai berikut:

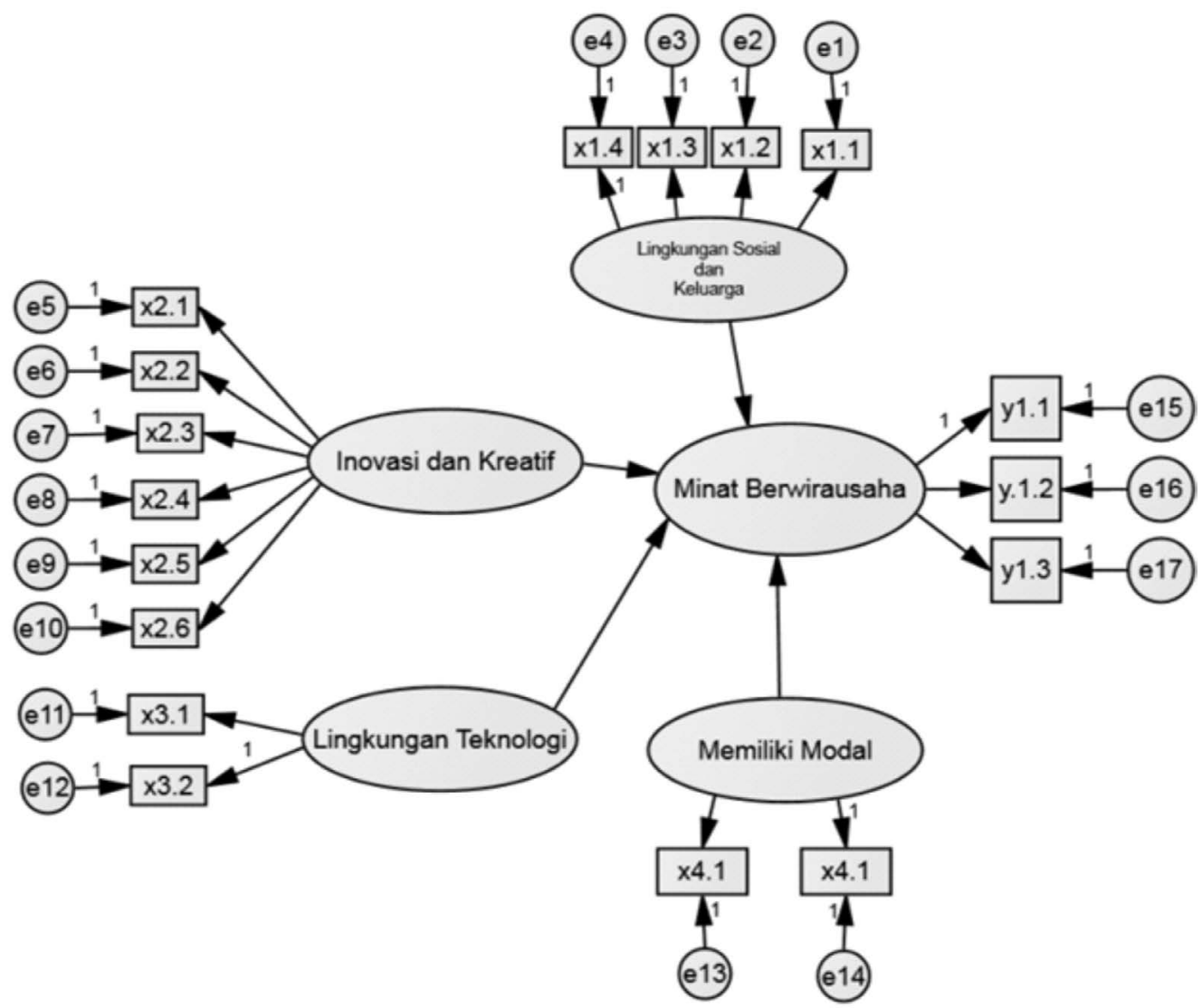

Sumber: Output SEM, 2016

Gambar 4.1 Path diagaram analisis faktor-faktor yang mempengaruhi mahasiswa dalam minat berwirausaha

Dengan:

$\mathrm{X}_{1}=$ Variabel eksogen lingkungan sosial dan keluarga

$\mathrm{X}_{2}=$ Variabel eksogen inovasi dan kreatifitas

$\mathrm{X}_{3}=$ Variabel eksogen lingkungan dan teknologi

$\mathrm{X}_{4}=$ Variabel eksogen memiliki moterdiri dari dal

$\mathrm{Y}_{1}=$ Variabel endogen Minat berwirausaha

\section{Model Persamaan}

Konversi path diagram model structural ke dalam model matematika bertujuan untuk menjelaskan bagaimana seharusnya model tersebut memiliki hubungan antar variabel. Adapun persamaan structural yang dikembangkan adalah sebagai berikut: 
Persamaan spesifikasi model pengukuran (measurement model): persamaan ini menentukan variabel yang mengukur konstruk, serta menentukan serangkaian matrik yang menghasilkan korelasi yang dihipotesiskan antar konstruk variabel.

1. Lingkungan sosial dan keluarga $\left(\mathrm{X}_{1}\right)$, yang terdiri dari latar belakang pekerjaan orang tua $\left(\mathrm{X}_{1.1}\right)$, kondisi ekonomi keluarga $\left(\mathrm{X}_{1.2}\right)$, bimbingan dan dorongan orang tua $\left(\mathrm{X}_{1.3}\right)$ dan motivasi teman yang berwirausaha $\left(\mathrm{X}_{1.4}\right)$.

$$
\begin{aligned}
& X_{1.1}=\alpha_{1} X_{1}+e_{1} \\
& X_{1.2}=\alpha_{2} X_{1}+e_{2} \\
& X_{1.3}=\alpha_{3} X_{1}+e_{3} \\
& X_{1.4}=\alpha_{4} X_{1}+e_{4}
\end{aligned}
$$

2. Inovasi dan kreatif $\left(\mathrm{X}_{2}\right)$, terdiri dari memiliki inisiatif $\left(\mathrm{X}_{2.1}\right)$, selalu mengutamakan imajinasi $\left(\mathrm{X}_{2.2}\right)$, memanfaatkan perbedaan $\left(\mathrm{X}_{2.3}\right)$, sikap tidak pernah puas $\left(\mathrm{X}_{2.4}\right)$, orisinil $\left(\mathrm{X}_{2.5}\right)$ dan berani tampil beda $\left(\mathrm{X}_{2.6}\right)$.

$$
\begin{aligned}
& \mathrm{X}_{2.1}=\alpha_{5} \mathrm{X}_{2}+\mathrm{e}_{5} \\
& \mathrm{X}_{2.2}=\alpha_{6} \mathrm{X}_{2}+\mathrm{e}_{6} \\
& \mathrm{X}_{2.3}=\alpha_{7} \mathrm{X}_{2}+\mathrm{e}_{7} \\
& \mathrm{X}_{2.4}=\alpha_{8} \mathrm{X}_{2}+\mathrm{e}_{8} \\
& \mathrm{X}_{2.5}=\alpha_{9} \mathrm{X}_{2}+\mathrm{e}_{9} \\
& \mathrm{X}_{2.6}=\alpha_{10} \mathrm{X}_{2}+\mathrm{e}_{10}
\end{aligned}
$$

3. Lingkungan dan tehnologi $\left(\mathrm{X}_{3}\right)$, terdiri kemajuan perkembangan tehnologi $\left(\mathrm{X}_{3.1}\right)$ dan kemudahan penggunaan internet $\left(\mathrm{X}_{3.2}\right)$.

$$
\begin{aligned}
& X_{3.1}=\alpha_{11} X_{3}+e_{11} \\
& X_{3.2}=\alpha_{12} X_{3}+e_{12}
\end{aligned}
$$

4. Memiliki Modal $\left(\mathrm{X}_{4}\right)$, terdiri dari tempat usaha yang strategis $\left(\mathrm{X}_{4.1}\right)$ dan keuangan modal yang strategis $\left(\mathrm{X}_{4.2}\right)$.

$$
\begin{aligned}
& \mathrm{X}_{4.1}=\alpha_{13} \mathrm{X}_{4}+\mathrm{e}_{13} \\
& \mathrm{X}_{4.2}=\alpha_{14} \mathrm{X}_{4}+\mathrm{e}_{14}
\end{aligned}
$$


5. Minat Berwirausaha $\left(\mathrm{Y}_{1}\right)$, terdiri dari persasaan tertarik untuk berwirausaha $\left(\mathrm{Y}_{1.1}\right)$, perasaan senang untuk berwirausaha $\left(\mathrm{Y}_{1.2}\right)$, bernniat untuk direalisasikan dimasa yang akan datang $\left(\mathrm{Y}_{1.3}\right)$.

$$
\begin{aligned}
& \mathrm{Y}_{1.1}=\alpha_{15} \mathrm{Y}_{1}+\mathrm{e}_{15} \\
& \mathrm{Y}_{1.2}=\alpha_{16} \mathrm{Y}_{1}+\mathrm{e}_{16} \\
& \mathrm{Y}_{1.3}=\alpha_{17} \mathrm{Y}_{1}+\mathrm{e}_{17}
\end{aligned}
$$

\section{Pemodelan PLS}

Metode analisis utama dalam penelitian ini dilakukan dengan structural Equation Model (SEM) dengan pemodelan menggunakan SmartPLS sebagai berikut:

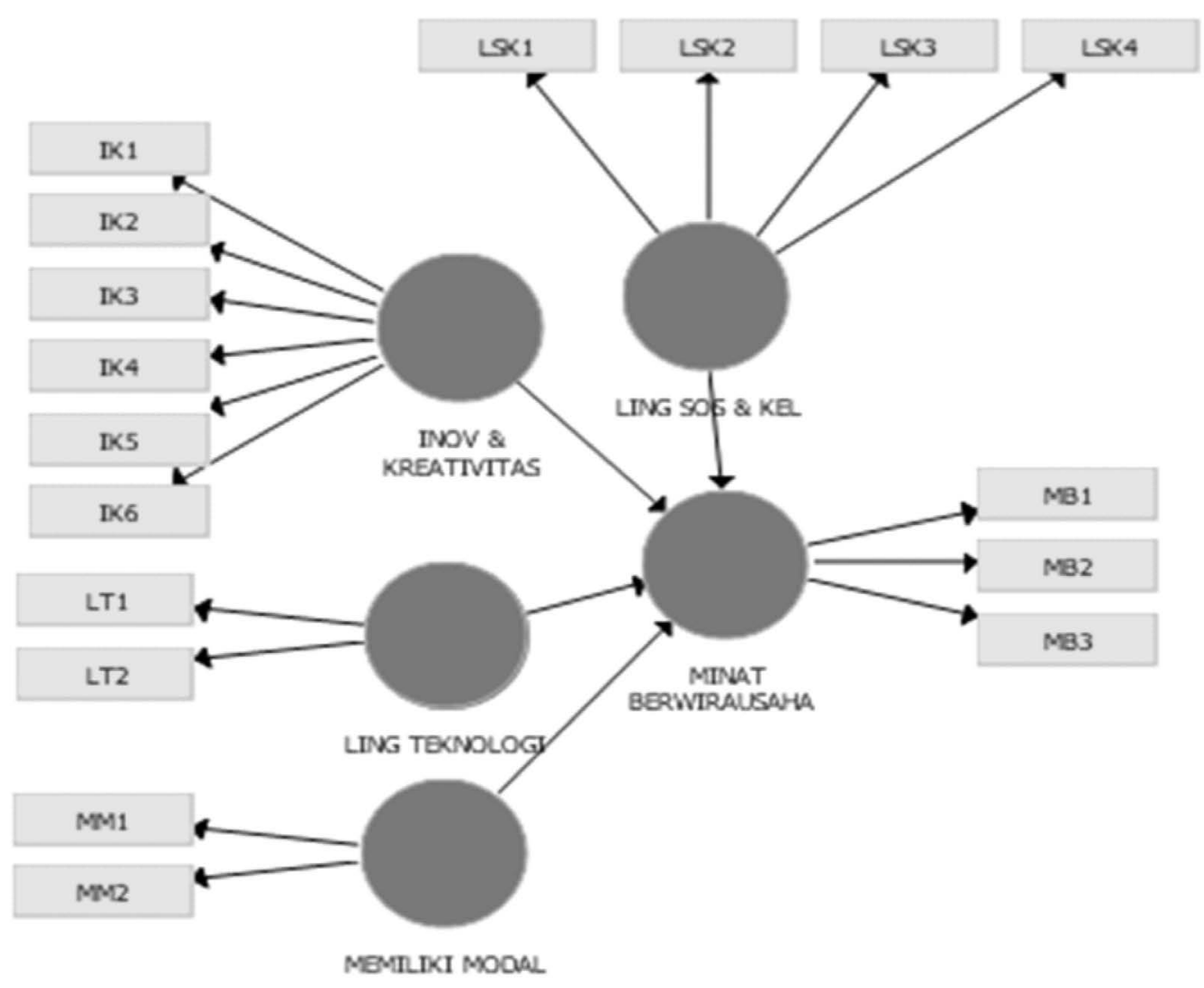

Sumber : Data diolah dari SmartPLS, 2016.

\section{Gambar 4.2 Pemodelan Menggunakan SmartPLS}

\section{Evaluasi Model}

1. Evaluasi Model Pengukuran

a. Composite Reliability 
Tabel 4.6 Composite Reliability

\begin{tabular}{|l|r|r|r|r|r|}
\hline & $\begin{array}{c}\text { Original } \\
\text { Sample } \\
(\mathbf{O})\end{array}$ & $\begin{array}{c}\text { Sample } \\
\text { Mean } \\
(\mathbf{M})\end{array}$ & $\begin{array}{c}\text { Standard } \\
\text { Deviation } \\
\text { (STDEV) }\end{array}$ & $\begin{array}{c}\text { T Statistics } \\
(\text { (IO/STDEV|) }\end{array}$ & $\begin{array}{c}\mathbf{P} \\
\text { Values }\end{array}$ \\
\hline INOV \& KREATIVITAS & 0.877 & 0.875 & 0.024 & 37.163 & 0.000 \\
\hline LING SOS \& KEL & 0.681 & 0.659 & 0.064 & 10.672 & 0.000 \\
\hline LING TEKNOLOGI & 0.952 & 0.949 & 0.018 & 53.120 & 0.000 \\
\hline MEMILIKI MODAL & 0.894 & 0.827 & 0.173 & 5.165 & 0.000 \\
\hline MINAT BERWIRAUSAHA & 0.885 & 0.886 & 0.023 & 39.030 & 0.000 \\
\hline
\end{tabular}

Berdasarkan tabel 4.6 diperoleh informasi bahwa nilai Composite Reliability pada semua blok indicator telah memenuhi asumsi Composite Reliability yakni lebih besar dari 0,6 artinya blok indikator pada masing-masing variabel laten memiliki konsistensi yang tinggi.

\section{Pemodelan Faktor-faktor yang mempengaruhi mahasiswa dalam minat berwirausaha}

Sebelum dilakukan uji hipotesis dilakukan prosedur bootstrapping pada data sampel. Bootstraping dilakukan sebanyak 500 kali dimana pada setiap kali bootstrapping data dilakukan, resampling yang diperoleh sebanyak 100 data valid. Hasil dari bootstrapping dengan sampel bootstrap sebanyak 500 kali diasumsikan data berdistribusi normal sehingga pengujian parameter dalam model dapat dilakukan dengan uji t.

\section{Pengujian dan Pembahasan Hipotesis}

Pengujian hipotesis yang diajukan, dapat dilihat dari besarnya nilai T-statististik. Signifikansi parameter yang diestimasi memberikan informasi yang sangat berguna mengenai hubungan antara variabel-variabel penelitian. Batas untuk menolak dan menerima hipotesis yang diajukan adalah $\pm 1,96$, dimana apabila nilai t berada pada rentang nilai $-1,96$ dan 1,96 maka hipotesis akan ditolak atau dengan kata lain menerima hipoteis nol $\left(\mathrm{H}_{0}\right)$. Tabel 4.7 memberikan output estimasi untuk pengujian model structural.

Tabel 4.7 Result For Inner Weight

\begin{tabular}{|l|r|r|r|r|c|}
\hline & $\begin{array}{c}\text { Original } \\
\text { Sample } \\
\text { (O) }\end{array}$ & $\begin{array}{c}\text { Sample } \\
\text { Mean } \\
\text { (M) }\end{array}$ & $\begin{array}{c}\text { Standard } \\
\text { Deviation } \\
\text { (STDEV) }\end{array}$ & $\begin{array}{c}\text { T Statistics } \\
\text { (|O/ } \\
\text { STDEV|) }\end{array}$ & \multicolumn{1}{c|}{$\begin{array}{c}\mathbf{P} \\
\text { Values }\end{array}$} \\
\hline $\begin{array}{l}\text { INOV \& KREATIVITAS -> MINAT } \\
\text { BERWIRAUSAHA }\end{array}$ & 0.389 & 0.399 & 0.122 & 3.204 & 0.001 \\
\hline $\begin{array}{l}\text { LING SOS \& KEL -> MINAT } \\
\text { BERWIRAUSAHA }\end{array}$ & 0.138 & 0.169 & 0.099 & 1.388 & 0.166 \\
\hline $\begin{array}{l}\text { LING TEKNOLOGI -> MINAT } \\
\text { BERWIRAUSAHA }\end{array}$ & 0.235 & 0.207 & 0.116 & 2.032 & 0.043 \\
\hline $\begin{array}{l}\text { MEMILIKI MODAL -> MINAT } \\
\text { BERWIRAUSAHA }\end{array}$ & -0.028 & -0.006 & 0.132 & 0.211 & 0.833 \\
\hline
\end{tabular}

Sumber : Output SmartPLS (Total Effect), 2016. 


\section{Pengaruh Lingkungan Sosial dan Keluarga terhadap Minat Berwirausaha}

Hipotesis pertama $\left(\mathrm{H}_{1}\right)$ yang menyatakan bahwa Lingkungan Sosial dan Keluarga berpengaruh positif terhadap Minat berwirausaha ternyata hipotesis tersebut tidak dapat diterima atau ditolak karena nilai t-statistiknya 1,388 dan tidak signifikan pada pada $\alpha=0,05$. Nilai t-statistic tersebut dibawah nilai kritis $\pm 1,96$. Temuan ini didorong dari jawaban responden yang mengidentifikasikan bahwa latar belakang pekerjaan orang tua, kondisi ekonomi keluarga dan motivasi teman yang berwirausaha tidak mempengaruhi mahasiswa dalam minat berwirausaha. Sedangkan bimbingan dan dorongan orang tua mempengaruhi mahasiswa dalam minat berwirausaha.

\section{Pengaruh Inovasi dan kreatifitas terhadap Minat Berwirausaha}

Hipotesis kedua $\left(\mathrm{H}_{2}\right)$ yang menyatakan bahwa Inovasi dan Kreatififitas berpengaruh positif terhadap Minat berwirausaha ternyata hipotesis tersebut diterima karena pengaruh inovasi dan kreatifitas terhadap Minat Berwirausaha mendapat hasil uji koefisien parameter antara inovasi dan kreatifitas terhadap Minat berwirausaha pada nilai 38,9\% (yaitu berdasarkan nilai entire sample estimate Inovasi dan kreatifitas -> Minat Berwirausaha pada nilai 0,389), dengan nilai t-statistik sebesar 3,204 dan signifikan pada $\alpha=0,05$. Nilai t-statistic tersebut diatas nilai kritis $\pm 1,96$.

\section{Pengaruh lingkungan dan teknologi terhadap Minat Berwirausaha}

Hipotesis ketiga $\left(\mathrm{H}_{3}\right)$ yang menyatakan bahwa Lingkungan \& Teknologi terhadap Minat Berwirausaha mendapatkan hasil uji koefisien parameter antara Lingkungan \& Teknologi terhadap Minat Berwirausaha pada nilai 23,5\% (yaitu berdasarkan nilai entire sample estimate Ligkungan \& Teknologi -> Minat Berwirausaha pada nilai 0,235) dengan nilai t-statistik 2,032 dan signifikan pada $\alpha=0,05$. Nilai t-statististik tersebut diatas dari nilai kritis $\pm 1,96$ dengan demikian hipotesisi kedelapan $\left(\mathrm{H}_{3}\right)$ dapat diterima

\section{Pengaruh Memiliki Modal terhadap Minat Berwirausaha}

Hipotesis keempat $\left(\mathrm{H}_{4}\right)$ yag menyatakan bahwa variabel Memiliki Modal terhadap Minat Berwirausaha mendapatkan hasil uji koefisien parameter antara Memiliki Modal terhadap Minat Berwirausaha pada nilai negative 2,8\% (yaitu berdasarkan nilai entire sample estimate Memiliki Modal -> Minat Berwirausaha pada nilai -0,028), dengan nilai t-statistic 0,164 dan tidak signifikan pada $\alpha=0,05$. Nilai t-statistik tersbut dibawah jauh dari nilai kritis $\pm 1,96$. Dengan demikian hipotesis ke empat $\left(\mathrm{H}_{4}\right)$ tidak dapat diterima atau ditolak.

Dari hasil uji ini bisa diidentifikasikan bahwa memiliki tempat usaha yang strategis dan modal yang cukup tidak berpengaruh terhadap minat berwirausaha, ini bisa dilihat pada saat ini dengan banyaknya wadah atau tempat memasarkan produk dengan sistem digital dan perilaku konsumen yang melakukan pembelian barang secara on-line. 


\section{KESIMPULAN DAN SARAN}

\section{Kesimpulan}

Berdasarkan hasil analisis data dan pembahasan dapat ditarik kesimpulan bahwa minat berwirausaha mahasiswa prodi Manajemen Fakultas Ekoonomi Universitas Kadiri sangat tinggi dan dari hasil uji statistik dari beberapa faktor yang mempengaruhinya adalah faktor inovasi dan kreatifitas serta lingkungan teknologi. Walaupun faktor-faktor yang lain seperti lingkungan sosial dan keluarga,berpengaruh positif tetapi tidak signifikan, karena nilai t-statistiknya dibawah dari nilai kritis $\pm 1,96$.

\section{Saran}

Dari kesimpulan diatas untuk tujuan mengembangkan minat berwirausaha pada mahasiswa Fakultas Ekonomi sebaiknya Fakultas memfasilitasi para mahasiswa dengan sarana prasarana teknologi untuk mengembangkan inovasi dan kreatifitasnya dengan membuat ekstra pengembangan diri mahasiswa sebagai pelaku wirausaha atau pelaku bisnis. Untuk referensi penelitian berikutnya di Fakultas Ekonomi Universitas Kadiri diadakan penelitian lagi dengan menambahkan faktor-faktor yang lain atau dengan menambahkan faktor lingkungan perguruan tinggi.

\section{DAFTAR PUSTAKA}

Alma, Buchari. (2010) Kewirausahaan (edisi revisi). Bandung: CV Alfabeta.,

Aris et al. (2013). Analisis Kepemilikan Jiwa wirausaha Pada Pelaku Usaha Kecil dan Menengah di Kota Depok. Bandung: Proceding PESAT (Psikologi, EKonomi, Sastra, Arsitektur \& Teknik Sipil). Vol. 5 Oktobers 2013. ISSN: 1858-2559

Ayuningtyas et al. (2015). Faktor-faktor yang mempengaruh Minat Berwirausaha Pada Mahasiswa Fakultas Ekonomi Universitas Tarumanegara. Jurnal Ekonomi: Volume XX, No. 01, Maret 2015.

Djaali. (2007). Psikologi pendidikan. Jakarta: Bumi Aksara.

Fuadi, I.F. 2009. Hubungan minat berwirausaha dengan prestasi praktikkerja industri siswa kelas XII teknikotomotif SMK Negri 1 Adiwerna Kabupaten Tegal." Jurnal PTM 9(1) Desember: 92-98.

Fatrika et al. Analisis Faktor-Faktor Yang Mempengaruhi Minat Wirausaha Mahasiswa Dengan Teknik SEM. Jurnal Matematika UNAND Vol. 1 No. 2 Hal. 5-12. ISSN 2303.2910

Koranti, Komsi. (2013). Analisis Pengaruh Faktor Eksternal dan Internal Terhadap Minat Berwirausaha. Bandung: Proceding PESAT (Psikologi, Ekonomi, Sastra, Arsitektur \& Teknik Sipil). Vol. 5 Oktober 2013. ISS: 1858-2559.

Leili et al. Faktor-faktor yang berpengaruh Terhadap Niat Kewirausahaan (entrepreneurial Intention) (Studi terhadap Mahasiswa Universitas Kristen Satya Wacana, Salatiga). Salatiga Fakultas Ekonomika dan Bisnis. Universitas Kristen Satya Wacana. 
McClelland, David. (1976) The Achievement Motive. Irvington Publishers, Inc. New York . (1995) Pengantar Kewiraswastaan. Jakarta: IntermediaNotoatmodjo,

Mahanani, Hanum R. (2014). Analisis Pengaruh Internal dan Faktor lingkungan Eksternal terhadap Minat Berwirausaha (Studi pada siswa SMA Negeri 1 Semarang). Semarang: fakultas Ekonomika dan Bisns. Universitas Diponegoro.

Praswati, Aflit N. (2014). Analisis Faktor-faktor Yang Mempengaruhi Minat Wirausaha Di Kalangan Mahasiswa Studi Kasus: Fakultas Ekonomika dan Bisnis Universitas Muhammadiyah Surakarta. Seminar Nasional dan Call for Paper (Sancall 2014). ISBN: 978-602-70429-1-9

Rosmiati et al. (2015) Sikap, Motivasi dan Minat Berwirausaha Mahasiswa. JMK. Vol 17 No. 1 Maret 2015

Subandono, A. (2007). Pengaruh Life Skill Diklat Kimia Produktif dan Prestasi Belajar Diklat Kewirausahaan terhadap Minat Berwirausaha pada Siswa SMK Kimia Industri Theresiana Semarang. Skripsi.FMIPA-UNES

Sugiyono (2007). Metode penelitian pendidikan, pen-dekatan kuantitatif, kualitatif, dan $R$ \& D. Ban-dung: Alfabeta

Suryana. (2006). Kewirausahaan Edisi 3. Jakarta: Salemba Empat.

Wibowo, M. (2011). Pembelajaran Kewirausahaan Dan Minat Wirausaha Lulusan SMK. Jurnal Ekplanasi. Volume 6 . Nomor 2 . Edisi September 2011 